International Journal of Social Sciences and Humanities
Available online at http://sciencescholar.us/journal/index.php/ijssh
Vol. 2 No. 3, December 2018, pages: $21 \sim 32$
e-ISSN: 2550-7001, p-ISSN: 2550-701X
https://doi.org/10.29332/ijssh.v2n3.187

\title{
Role of Anggah-Ungguh Kruna in Balinese Language Sentence Formation
}

\section{Nyoman Suwija ${ }^{a}$}

Article history: Received 5 April 2018, Accepted: 30 August 2018, Published: 11 September 2018

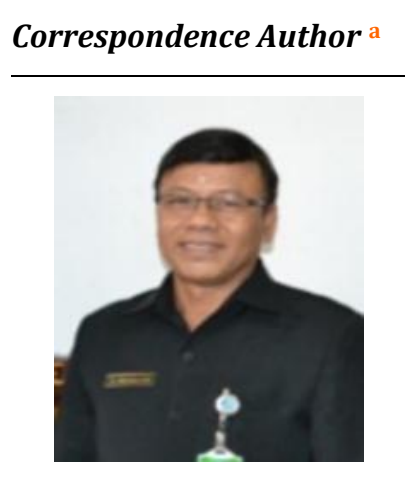

Keywords

Addressed Level; Anggah-ungguh Kruna; Balinese Language Sentence;

Sentence Formation; Sociolinguistics;

\begin{abstract}
Balinese language, as a large local language in Indonesia still exists, unlike mandatory local content at the level of primary and secondary education. Scrutinizing the importance of Balinese language role for the Balinese tribes, therefore, Balinese local languages should be maintained, nurtured, and preserved. This study was intended to describe the role of the Balinese language in the sentences formation. In order to achieve the goal, the sociolinguistic theory was used in the present study. In collecting data, the observation method and interview method were used. The data collected were analyzed using distributional methods. The formal and informal methods were applied in the presentation of the results of the data analysis. It was supported by an inductive and the deductive techniques. Based on the anggah-ungguh kruna as its formation, the Balinese sentence was divided: (1) alus singgih sentence, (2) alus sor sentence, (3) alus mider sentence, (4) alus madia sentence, (5) andap sentence, and (6) kasar sentence.
\end{abstract}

e-ISSN: 2550-7001, p-ISSN: 2550-701X ${ }^{\odot}$ Copyright 2018. The Author. SS Journals Published by Universidad Técnica de Manabí. This is an open-access article under the CC BY-SA 4.0 license (https://creativecommons.org/licenses/by-sa/4.0/) All rights reserved.

\section{Contents}

Abstract

1. Introduction

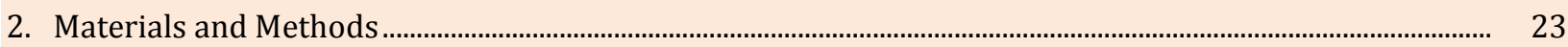

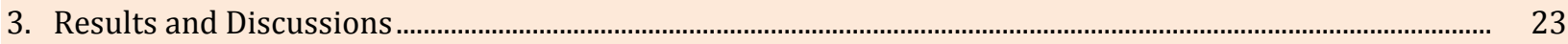

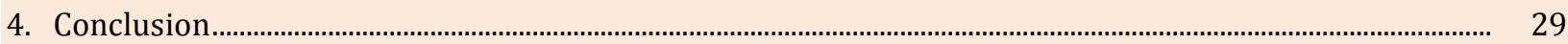

Acknowledgements........................................................................................................................................................... 30

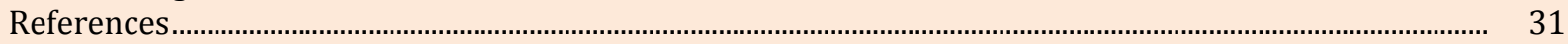

Biography of Authors ........................................................................................................................................... 32

a Indonesian and Local Language Education Studies Program, Faculty of Language and Art Education, IKIP PGRI Bali 


\section{Introduction}

The Balinese language is one of the major languages in Indonesia. Due to it is still used as a communication tool in the intercommunication of the Balinese society. This is a reason why the Balinese language should be maintained, nurtured, and preserved. The local government in Bali has given serious attention to the maintenance of the Balinese language. Due to it is believed that the Balinese language is a mode as well as the roots of the Balinese culture. Wherein, the Balinese culture is Balinese tourism foundation.

Realizing the above case, in 2013 the Governor Regulation No. 20 was issued concerning the affirmation of the Balinese Language as a mandatory local content at the primary and secondary education levels. In April 2018, the Regional Regulation of Bali No. 1 was issued again about Balinese Language, Literacy, and Literature. In term of this greatly strengthens the status of the Balinese language as the mother tongue of the Balinese society that should be preserved. It gives a signal that before learning Indonesian and/or a foreign language, the Balinese children must be the first speaker of the native language from their birth in their respective families. Therefore, they do not lose their identity as a Balinese society (Suwija: 2017, Suryasa \& Dewi: 2018).

The government aim is to give serious attention to the existence of Balinese local languages. In order to the Balinese people from their children learn the good and right Balinese language through formal education. Speech skills are the ultimate goal that is very important for someone who studies the language. It is in accordance with Tarigan (1986: 3-4), the opinion stated that speech is the one's ability to pronounce articulation sounds or words to express their thoughts, ideas, and feelings.

Djiwandono (1996: 68), stated that in a speech the one tries to express his/her thoughts and feelings to others verbally. Without trying to reveal him/her self, the others will not know what is being thought and felt. Speech is an active productive language activity required the real initiatives in the language used to be able to express themselves verbally.

Regarding this research is a formal expression that meets the principles of the oral language that is good and right. Everyone basically has oral language skills, but when appointed speech to present in the official forums, many feel unable or not confident. Even worse in the speech of the Balinese language, due to the speech system is a legacy of the Balinese society which is unique. The uniqueness is meant that the Balinese language has vocabularies consists of the value of alus (mellow) or kasar (rude). It is called anggah-ungguhing basa Bali (addressee of Balinese language level) or speech levels of the Balinese language. In term of this has been passed down through generations, well understood by the Balinese society when they have to communicate with Balinese language media.

Since 1974, through Pasamuhan Agung Basa Bali in Singaraja, the speech level of Balinese language is called Anggah-ungguhing Basa Bali. Before in 1957, 1970, 1984, Kersten called it in term of the Warna-Warna Bahasa Bali (Balinese language varieties). The Tim Peneliti Fakultas Sastra Universitas Udayana (The Research Team of the Faculty of Art, Udayana University) (1988/1989), called it as Unda Usuk Bahasa Bali. Tinggen (1984), until currently using Sor Singgih Basa Bali term. Naryana (1983), called it Anggah-ungguhing Basa Bali. Suarjana (2011), still uses Anggah-ungguhing Basa Bali term. Suwija (2014), called it anggah-ungguh basa Bali.

The existence of anggah-ungguh basa is accepted long ago and is still in use currently, due to there are pabinayan linggih (different positions) of the Balinese societies. The existence of the social stratification for them, unlike the Balinese Purwa (traditional) and the Balinese Anyar (modern society), has caused the Balinese to speak accordingly tata linggih (position structure) which are called masor singgih basa or speak accordingly to anggah-ungguh basa Bali.

To each Balinese language, the speaker must pay attention to who is invited to speak, who is the speech partner. The lexicon choice in the sentence will be different. When talking about yourself, you have to use alus sor sentences, if you speak to the sang singgih (honorable person) using alus singgih sentence. If speech about own or our family, we have to call it ipun (she/he) pronoun, even though (s/he) uses alus sor sentence.

This study aims at describing the role of anggah-ungguh kruna basa Bali in Balinese sentences formation. Fishman (1986), the sociolinguistic theory is used. According to Fishman (1986), sociolinguistic studies about behavior includes the background, topic, and interaction function. It does not focus attention on linguistic 
phenomena only but also focuses on the problem of the language attitudes, real behavior towards language and language users.

Koentjaraningrat (1990), stated that in a language there is a system of the words used is called kinship. The kinship system has a close relationship with language social behavior. The Balinese society included two groups, i.e., triwangsa and wangsa jaba societies. Triwangsa is used to refer to three castes (brahmana, ksatria, and sudra) who receive respect through language and may speak the ordinary language to the wangsa jaba. Meanwhile, the wangsa jaba is the name of the most people who are obliged to speak Balinese alus (respect) to the triwangsa. This situation is due to the Balinese sentence to be very varied (Ginaya: 2018).

\section{Materials and Methods}

The qualitative methods are used in the study. Djajasudarma (2006:10), was stated regarding qualitative methods application. It is the procedures that produce descriptive data, both written and oral which develop or there is in the society (in Sofyan, 2015: 263). Sofyan (2015), further stated that related to this method, the data is descriptively produced with the intention is to make a systematic, factual, and accurate description, describing, and data regarding the data, nature, and related to the phenomena.

The descriptive method is equipped with the three methods and techniques, i.e., data collection methods and techniques, data analysis methods and techniques, as well as methods and techniques for presenting the results of the data analysis (Sudaryanto, 1982). The data collection of the study uses the simulations method. This is in accordance with Sudaryanto (1993: 133), opinion that in the observe method and the technique is used which included tapping, capable involvement, free observe refer to interview, record, and note taking (in Sofyan: 2015: 263). Furthermore, according to Firdaus (2011: 226), data analysis, using the equivalent method, is a method used to examine or determine diagonal unit identity using determinant that is language outside, regardless of the language in question (Firdaus, 2011: 226). The presentation of data analysis results using formal and informal methods, supported by an inductive and the deductive techniques.

\section{Results and Discussions}

Balinese language sentence formation is very determined by anggah-ungguh kruna or the levels of the Balinese word itself. What is the sentence meant, in this case, is utterance which consists of the subject as the main sentence, followed by the designation or predicate, which is accompanied by the object sentence, and is usually equipped with the necessary information. Thus, the sentence forming element is a clause; the clause is built from phrases in the phrases form and the smallest forming element is kruna or word.

The words of the Balinese language as sentence-forming elements are seven types or levels, included: (1) kruna alus mider, the words that have subtle-function values (can be used in the alus singgih and alus sor sentences), (2) kruna alus madia, the words that have intermediate subtle-forms for the main elements of alus madia sentences, (3) kruna alus singgih, the words that have a high sense value and specifically to respect the upper class or high status society, (4) kruna alus sor, the words that have a subtle-sense value to demean someone whose social status is attenuated, (5) kruna andap, the words that value ordinary sense or disrespectful to mention ordinary people state, (6) kruna mider, the Balinese words that does not have an alus form, and (7) kruna kasar, the Balinese words group that bad sense.

The words above will play a role in forming a Balinese sentence called lengkara. Lengkara is a linguistic term used refers to sentences in the Balinese language. A sentence is a form of language in the words collection accordingly to their respective benefits which consist of complete meaning. Thus, Balinese language sentence will be formed by the Balinese vocabulary which has a fine-grained sense value, therefore, in learning the Balinese language, there is anggah-ungguh lengkara material (the levels of the Balinese sentence).

Based on the sensed value by the forming element of anggah-ungguh kruna, the Balinese language is divided into six types, included: (1) alus singgih sentence; (2) alus madia sentence; (3) alus sor sentence; (4) alus mider sentence, (5) andap sentence; and (6) kasar sentences.

Suwija, I. N. (2018). Role of anggah-ungguh kruna in Balinese language sentence formation. International Journal of Social Sciences and Humanities, 2(3), 21-32. https://doi.org/10.29332/ijssh.v2n3.187 
1. Alus Singgih sentence

Alus Singgih sentence is the Balinese language that is high address sense, is used to respect people of the higher caste. It is generally is formed with words that have an alus sense. However, not all the words are formed have an alus singgih sense value. Alus singgih sentences are formed by the words alus singgih, alus mider, and mider. See the following example of alus singgih sentences!

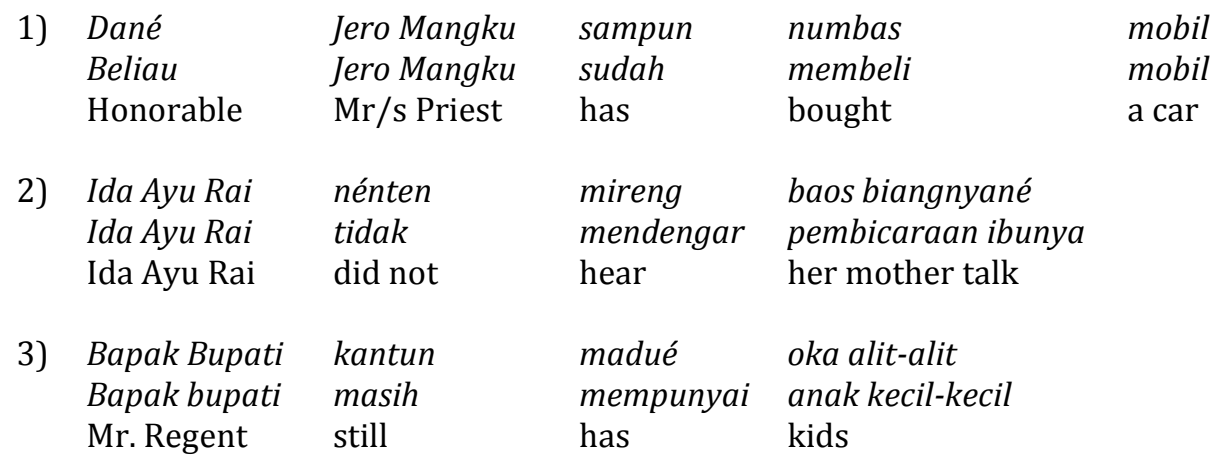

In example (1) alus singgih sentence is formed by the words "dane jero mangku" (kruna alus singgih), the word sampun (kruna alus mider), the word numbas (kruna alus mider), and the word mobil (kruna mider). In the sentence example (2), alus singgih sentence is formed from the noun (name) Ida Ayu Rai (kruna alus singgih), the word nenten (kruna alus mider), the word mireng (kruna alus singgih), the word baos (kruna alus singgih), and the word biangnyane (kruna alus singgih). In the example (3), alus singgih sentence is formed from the phrase bapak bupati (kruna andap), the word kantun (kruna alus mider), the word madue (kruna alus singgih), the word oka (kruna alus singgih), and the word alit-alit (kruna alus mider).

2. Alus Madia sentence

Alus madia sentence is the Balinese language that thas an alus sense value, however, they are still slightly lower because the forming element still words classified as kruna alus madia (middle word group). Thus, alus madia sentence will be felt by the speakers to have a moderate sense of value. Alus madia sentence is many using the alus madia words which value is sense middle. It is often added with alus mider words, mider words, and andap words. Look at the example sentences below!

\begin{tabular}{|c|c|c|c|c|c|}
\hline \multirow[t]{3}{*}{ 1) } & Tiang & nunasang & $\begin{array}{l}\text { antuk linggih } \\
\text { Jeroné? }\end{array}$ & & \\
\hline & Saya & menanyakan & status Anda? & & \\
\hline & I & ask & about your status? & & \\
\hline \multirow[t]{3}{*}{ 2) } & Pak-pak & dados & tiang & ten semprot & Pak? \\
\hline & Pakpak, & mengapa & saya & $\begin{array}{l}\text { tidak } \\
\text { disemprot, }\end{array}$ & Pak? \\
\hline & Sir, Sir, & why & am I & not sprayed, & sir? \\
\hline \multirow[t]{3}{*}{ 3) } & Tiang & kari & nyemak & motor & \\
\hline & Saya & masih & mengambil & motor & \\
\hline & & still & take & the motorbike & \\
\hline
\end{tabular}

Example sentences (1) above are derived from the word tiang 'I' (kruna alus madia), the nunasang 'asking' (kruna alus mider), the word linggih 'status' (kruna alus mider), the word jerone 'you' (kruna alus singgih). 
Examples for sentence (2) above are derived from the word pak-pak 'Sir' (kruna andap), the word dados 'why' (kruna alus mider), the word tiang 'I' (kruna alus madia), tiang ten 'not' (kruna alus madia), the word spray' spray '(kruna mider), and the word pak' ayah '(kruna andap). The sentence (3) above is formed from words: 'I' pole (kruna alus madia), the word semprot 'utterance' (kruna alus mider), the word nyemak 'take' (kruna alus mider), and the word motor 'motorbike' (kruna mider).

3. Alus Sor Sentence

Balinese language sentences contain subtle sense values and are often used to humble themselves or demean others because of their lower social status, it is called alus sor sentence. It is generally formed by alus sor, alus mider, andap, and mider words. Look at the example of alus sor sentence below!

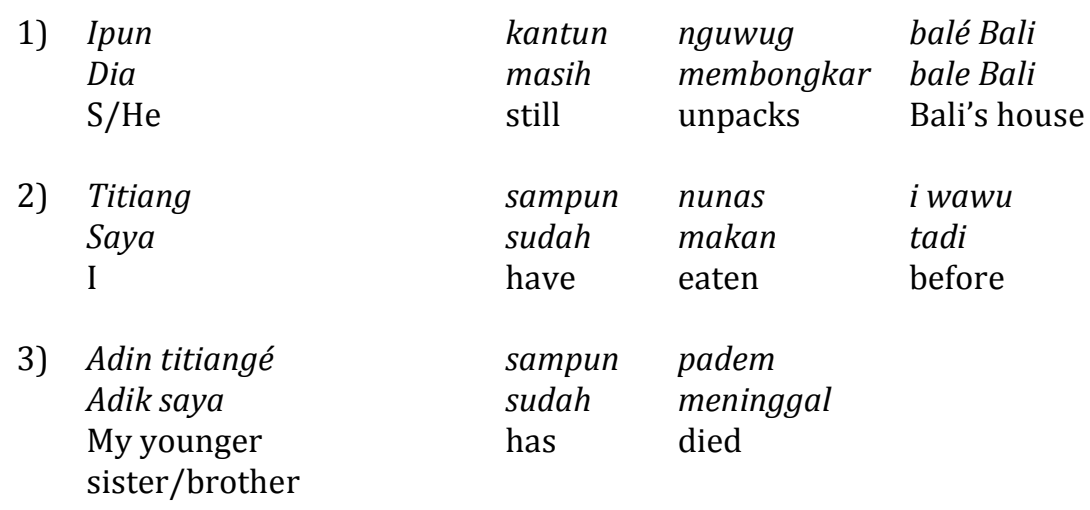

The sentence (1) is formed from the word ipun 's/he (kruna alus sor), the word kantun 'still' (kruna alus mider), the word nguwug 'unpack' (kruna andap) and the word Bali (kruna andap). The sentence (2) above is formed from the word titiang 'I' (kruna alus sor), the word sampun 'already' (kruna alus mider), the word nunas 'eat' (kruna alus sor), and the word iwawu 'before' '(kruna alus mider). Sentence (3) is formed from the word adin 'sister/brother' (kruna andap), the word titiange 'my' (kruna alus sor), the word sampun 'has' (kruna alus mider), and the word padem 'died' (kruna alus sor).

4. Alus Mider sentence

Alus mider sentence is used to speak simultaneously by the one who speech with their partner. Alus mider sentence is mostly formed with alus mider words added mider words. Look the following example of alus mider sentences below!

\begin{tabular}{|c|c|c|c|c|}
\hline 1) & $\begin{array}{l}\text { Ngiring iraga } \\
\text { Mari kita } \\
\text { Let's we }\end{array}$ & $\begin{array}{l}\text { sareng-sareng } \\
\text { ikut } \\
\text { join }\end{array}$ & $\begin{array}{l}\text { ngastiti } \\
\text { memuja } \\
\text { in worshiping }\end{array}$ & $\begin{array}{l}\text { Hyang Widhi } \\
\text { Tuhan Yang Maha Esa } \\
\text { God Almighty }\end{array}$ \\
\hline 2) & $\begin{array}{l}\text { Ida-dané sinamian } \\
\text { Hadirin sekalian } \\
\text { Ladies and gentlemen, }\end{array}$ & $\begin{array}{l}\text { ngiring } \\
\text { mari } \\
\text { let's }\end{array}$ & $\begin{array}{l}\text { kawitin } \\
\text { dimulai } \\
\text { start }\end{array}$ & $\begin{array}{l}\text { paruman druéné } \\
\text { rapat kita } \\
\text { our meeting }\end{array}$ \\
\hline 3) & $\begin{array}{l}\text { Iraga } \\
\text { Kitalah } \\
\text { We }\end{array}$ & $\begin{array}{l}\text { sané patut } \\
\text { yang harus } \\
\text { who should } \\
\text { be }\end{array}$ & $\begin{array}{l}\text { ngrajegang } \\
\text { melestarikan } \\
\text { preserved }\end{array}$ & $\begin{array}{l}\text { budaya Baliné } \\
\text { budaya Bali } \\
\text { Balinese culture }\end{array}$ \\
\hline
\end{tabular}

Suwija, I. N. (2018). Role of anggah-ungguh kruna in Balinese language sentence formation. International Journal of Social Sciences and Humanities, 2(3), 21-32. https://doi.org/10.29332/ijssh.v2n3.187 
Example sentences (1) are formed from the words ngiring 'let' (kruna alus mider), the word iraga 'we' (kruna mider), the word sareng-sareng 'together' (kruna alus mider), the word ngastiti 'worshiping' (kruna alus mider), and the words Ida Sang Hyang Widhi 'Supreme God' (kruna alus singgih). The sentences (2) above is formed from the words ida dane 'ladies and gentlemen' (kruna alus singgih), the word sinamian 'all' (kruna alus mider), the word ngiring 'let' (kruna alus mider), the word kawitin 'start' (kruna alus mider), the word paruman 'meeting' (kruna alus mider), and the word druéné 'our' (kruna alus mider). The sentences (3) is formed from the word iraga 'we' (kruna mider), the word sane 'who' (kruna alus mider), the patut 'should' (kruna alus mider), the word ngrajegang 'preserved' (kruna andap), the word budaya 'culture' (kruna andap), and the word Baline 'Bali' (kruna andap).

\section{Andap sentence}

The Andap sentences are Balinese langauge sentences which have ordinary sense values, not rough nor smooth. Andap language sentences are used in Balinese conversations between people with the same social status or by people with a higher social status towards the lower. Look the following example of the sentences!

\begin{tabular}{|c|c|c|c|c|c|c|}
\hline 1) & $\begin{array}{l}\text { I bapa } \\
\text { Ayah } \\
\text { Father }\end{array}$ & $\begin{array}{l}\text { mara pesan } \\
\text { baru saja } \\
\text { just }\end{array}$ & $\begin{array}{l}\text { majalan } \\
\text { berangkat } \\
\text { left }\end{array}$ & $\begin{array}{l}\text { lakar } \\
\text { akan } \\
\text { will }\end{array}$ & $\begin{array}{l}\text { ngebah } \\
\text { menebang } \\
\text { cut }\end{array}$ & $\begin{array}{l}\text { tiing tali } \\
\text { bambu tali } \\
\text { bamboo ropes }\end{array}$ \\
\hline 2) & $\begin{array}{l}\text { Nyén ja } \\
\text { Siapa sih } \\
\text { Who is }\end{array}$ & $\begin{array}{l}\text { adan } \\
\text { nama } \\
\text { the name }\end{array}$ & $\begin{array}{l}\text { timpal } \\
\text { temannya } \\
\text { of his friend }\end{array}$ & $\begin{array}{l}\text { Wayané? } \\
\text { Wayan? } \\
\text { Wayan? }\end{array}$ & & \\
\hline & $\begin{array}{l}\text { Icang } \\
\text { Saya } \\
\text { I }\end{array}$ & $\begin{array}{l}\text { lakar } \\
\text { mau } \\
\text { want }\end{array}$ & $\begin{array}{l}\text { ngecét } \\
\text { mengecet } \\
\text { to color }\end{array}$ & $\begin{array}{l}\text { témbok } \\
\text { tembok } \\
\text { the wall }\end{array}$ & $\begin{array}{l}\text { malu } \\
\text { dahulu } \\
\text { first }\end{array}$ & \\
\hline
\end{tabular}

Examples of sentences (1) are formed from the words I bapa 'father' (kruna andap), the word mara 'just' (kruna andap), the word pesan 'merely' (kruna andap), the word majalan 'left' (kruna andap), the word lakar 'will' (kruna andap), the word ngebah 'cut' (kruna andap), the word tiing 'bamboo' (kruna mider), and the word tali 'ropes' (kruna mider). The sentence (2) is formed from the word nyen 'who' (kruna andap), the word ja 'is' (kruna mider), the word adan 'name' (kruna andap), the word timpal 'friend' (kruna andap), and the word Wayane 'Wayan/the first nickname for Balinese people' (kruna mider). The sentence (3) is formed from the word icang 'I' (kruna andap), the word lakar 'will' (kruna andap), the word ngecét 'color' (kruna mider), the word témbok'wall' (kruna mider).

6. Kasar sentence

Kasar sentence is a Balinese language sentence has a bad or low sense value. Even, not all the words form up the kasar sentences are kruna kasar, however, also added to the andap words and the mider word. Look at the examples of the kasar sentences below!

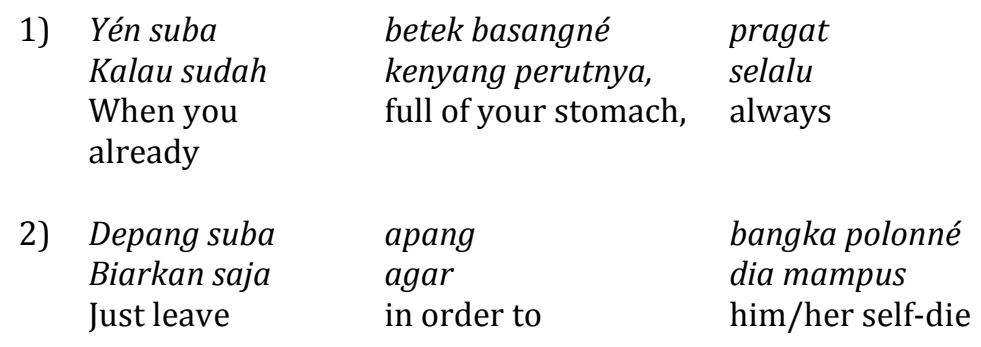

mamelud gaéné tidur kerjanya

sleep all the time 
3) Men Cai ngléklék Kamu mengapa Why do you ngaé membuat build
$W C$

$W C$

a toilet di

di

in sanggah?

tempat suci?

a holy place?

Examples for sentence (1) is formed from the word yen/yening 'when' (kruna andap), the word suba 'already' (kruna andap), the word betek 'full' (kruna kasar), the word basangne 'him/her stomach (kruna andap), the word pragat ' always' (kruna andap), the word memelud 'sleep' (kruna kasar), and the word gaenne 'his/her do' (kruna andap). The sentence (2) is formed from the word depang 'let' (kruna andap), the word suba 'already' (kruna andap), the word apang 'agar' (kruna andap), the word bangka 'mati' (kruna rough), and the word 'polonne' him/her self' (kruna kasar). The sentence (3) is formed from the following words. The word men 'if' (kruna andap), the word cai 'you' (kruna andap), the word nglekklek 'eat' (kruna kasar), the word di 'in' (kruna andap), the word sanggah 'holy place' (kruna andap), the word ngae 'build' (kruna andap), and the word WC 'toilet' (kruna mider).

Observing the above sentence examples, it can be ascertained that the characteristics of Balinese language sentences formation can be used, included alus singgih sentences, alus sor sentences, alus mider sentences, alus madia sentences, andap sentences, or kasar sentences are pronouns.

1) If the speaking partner is the upper class (sang singgih) unlike Ida, Dane, Ida-dane, Gusti Ayu, etc. Then, it can be ascertained that used alus singgih sentence. Examples:
a) Ida pedanda

$\begin{array}{ll}\begin{array}{l}\text { sampun } \\ \text { munggah }\end{array} & \text { jagi } \\ \text { sudah naik } & \text { akan } \\ \text { has been up } & \text { will }\end{array}$
ngastawayang
wangi druene
Ida pedanda
has been up
will
menghaturkan
sajian kita
Ida pedanda
sampun puput
sudah selesai
has finished
ngastawayang
menghaturkan
his mantra
being mantra
our offerings
b) Dane jero mangku
Dane jero mangku
bukus
buku
aturan druene
sajian kita
Dane jero mangku
sampun naur
sudah
membayar
has paid
the book
For our offerings

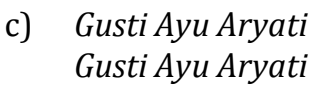
Gustu Ayu Aryati

ane katurang
yang diberikan
given
dibi?
kemarin?
yesterday?

2) If the speaking partner is the upper class (sang singgih) and talking about the ordinary people (sang sor), unlike titiang, ipun, adinipune, memen titiange, then it is used alus sor sentence. Examples:

\begin{tabular}{|c|c|c|c|c|c|c|}
\hline a) & $\begin{array}{l}\text { Nawegang } \\
\text { Ratu, }\end{array}$ & $\begin{array}{l}\text { rahinane } \\
\text { dibi }\end{array}$ & titiang nenten & $\begin{array}{l}\text { prasida } \\
\text { tangkil, }\end{array}$ & duaning & $\begin{array}{l}\text { buntut titiange } \\
\text { sakit pisan }\end{array}$ \\
\hline & $\begin{array}{l}\text { Maafkan Ratu, } \\
\text { Forgive the } \\
\text { Queen, }\end{array}$ & $\begin{array}{l}\text { hari } \\
\text { kemarin } \\
\text { yesterday }\end{array}$ & saya tidak & $\begin{array}{l}\text { sempat } \\
\text { menghadap, } \\
\text { have time to } \\
\text { pray, }\end{array}$ & $\begin{array}{l}\text { karena } \\
\text { because }\end{array}$ & $\begin{array}{l}\text { kaki saya sakit } \\
\text { sekali } \\
\text { my legs very hurt }\end{array}$ \\
\hline & $\begin{array}{l}\text { Sane mangkin } \\
\text { Sekarang }\end{array}$ & $\begin{array}{l}\text { Luh Rai } \\
\text { Luh Rai }\end{array}$ & $\begin{array}{l}\text { durung prasida } \\
\text { belum mampu }\end{array}$ & $\begin{array}{l}\text { naur } \\
\text { utangnyane } \\
\text { membayar }\end{array}$ & $\begin{array}{l}\text { duaning } \\
\text { karena }\end{array}$ & $\begin{array}{l}\text { ipun durung } \\
\text { kocap polih gajih } \\
\text { belum katanya }\end{array}$ \\
\hline
\end{tabular}

Suwija, I. N. (2018). Role of anggah-ungguh kruna in Balinese language sentence formation.

International Journal of Social Sciences and Humanities, 2(3), 21-32. 


\begin{tabular}{|c|c|c|c|c|c|}
\hline Now & Luh Rai & $\begin{array}{l}\text { Hasn't been able } \\
\text { to pay }\end{array}$ & $\begin{array}{l}\text { hutangnya } \\
\text { her debt }\end{array}$ & because & $\begin{array}{l}\text { mendapat gaji } \\
\text { she hasn't got a } \\
\text { salary }\end{array}$ \\
\hline $\begin{array}{l}\text { Padalem } \\
\text { titiang }\end{array}$ & $\begin{array}{l}\text { Beli } \\
\text { Wayan, }\end{array}$ & adinipune padem & $\begin{array}{l}\text { nyeburang } \\
\text { dewek }\end{array}$ & ring & $\begin{array}{l}\text { rumah sakit } \\
\text { Kapal }\end{array}$ \\
\hline $\begin{array}{l}\text { Kasihan saya } \\
\text { pada } \\
\text { My a pity for }\end{array}$ & $\begin{array}{l}\text { Beli } \\
\text { Wayan, } \\
\text { Beli } \\
\text { Wayan, }\end{array}$ & $\begin{array}{l}\text { adiknya } \\
\text { meninggal } \\
\text { his brother died }\end{array}$ & $\begin{array}{l}\text { menyeburkan } \\
\text { dirinya } \\
\text { jumping } \\
\text { him/her self }\end{array}$ & $\begin{array}{l}d i \\
\text { at }\end{array}$ & $\begin{array}{l}\text { rumah sakit } \\
\text { Kapal } \\
\text { Kapal Hospital }\end{array}$ \\
\hline
\end{tabular}

3) If the speaking partner is using alus sor language to the one who deserves respect and calls him/herself with tiang 'I' pronoun definitely the sentence used alus madia sentence. Examples: Sudah saya
I already
a) Ampun tiang
sane ngwehinipun surat yang memberikan surat gave the letter
di kalih rahina
dua hari yang lalu
tiang pegawe negeri tugas
saya pegawai negeri tugas
ring
di
am my official civil service at
Kantor Bupati Badung Kantor Bupati Badung I the Badung Regent's Office
c) Dumun ipun Dahulu dia
dados klian, menjadi kelian,
mangkin sekarang
In the past he became kelian,
now
ampun tiang sudah saya
I have
sane ngentosin yang menggantikan replaced it

4) The speaker at an official meeting as customs or Hindu religion use iraga or druene 'we' pronouns, it is certain that the language used alus mider sentence.

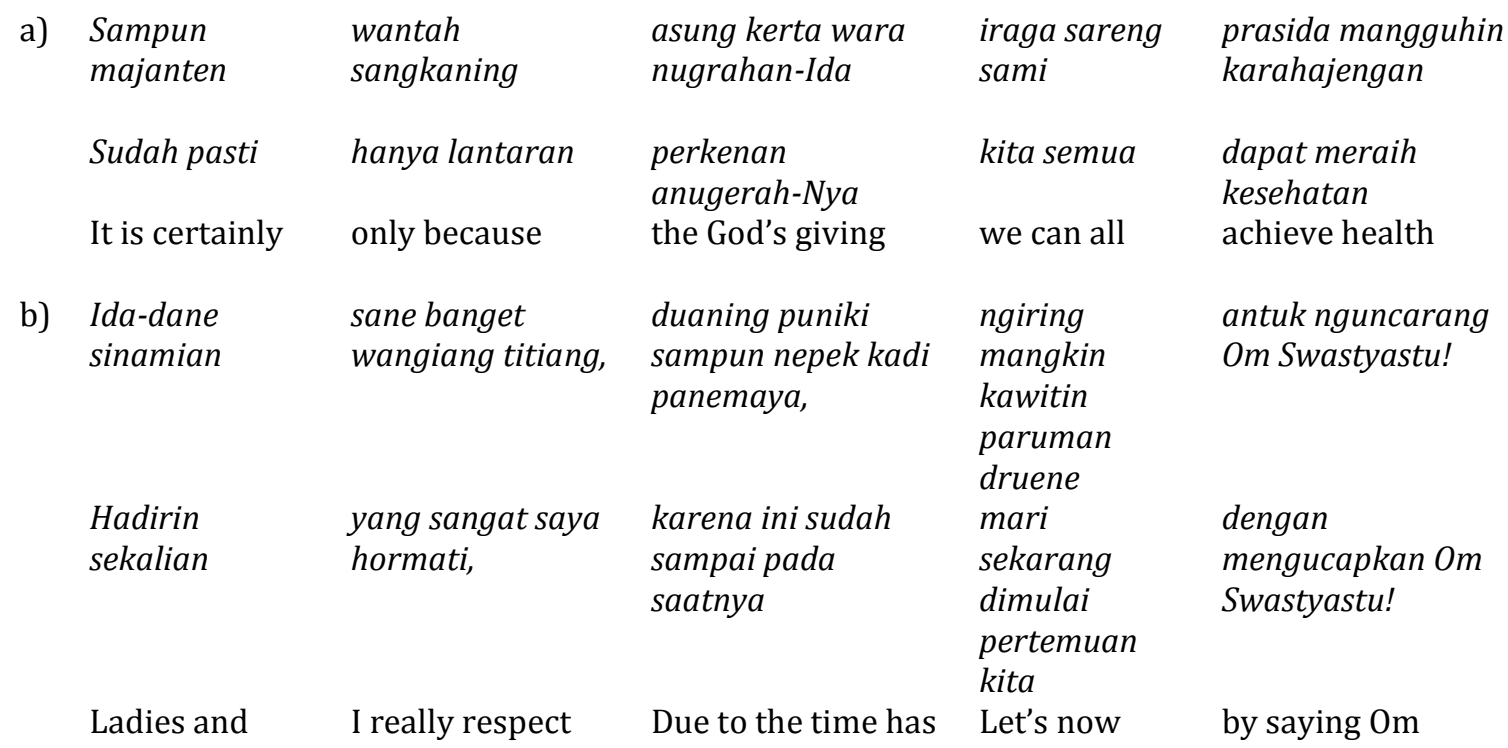




\begin{tabular}{|c|c|c|c|c|}
\hline & Gentlemen, & & to begin, & Swastyastu! \\
\hline c) & Sane patut & $\begin{array}{l}\text { ngrajegang basa } \\
\text { Baline }\end{array}$ & $\begin{array}{l}\text { wantah iraga } \\
\text { sareng sami } \\
\text { kamanggala }\end{array}$ & olih sang maraga guru wisesa \\
\hline & Yang harus & $\begin{array}{l}\text { melestarikan } \\
\text { bahasa Bali }\end{array}$ & $\begin{array}{l}\text { hanya kita sekalian } \\
\text { dipipimpin }\end{array}$ & oleh para pejabat setempat \\
\hline & Only those & $\begin{array}{l}\text { who have to } \\
\text { preserve the } \\
\text { Balinese } \\
\text { language }\end{array}$ & only we all & are led by the local officials \\
\hline
\end{tabular}

5) If the speakers use the pronoun andap level, unlike icang, iang, ia, I made, it can be ascertained that the sentence that will be used is a basic sentence like in the following example.

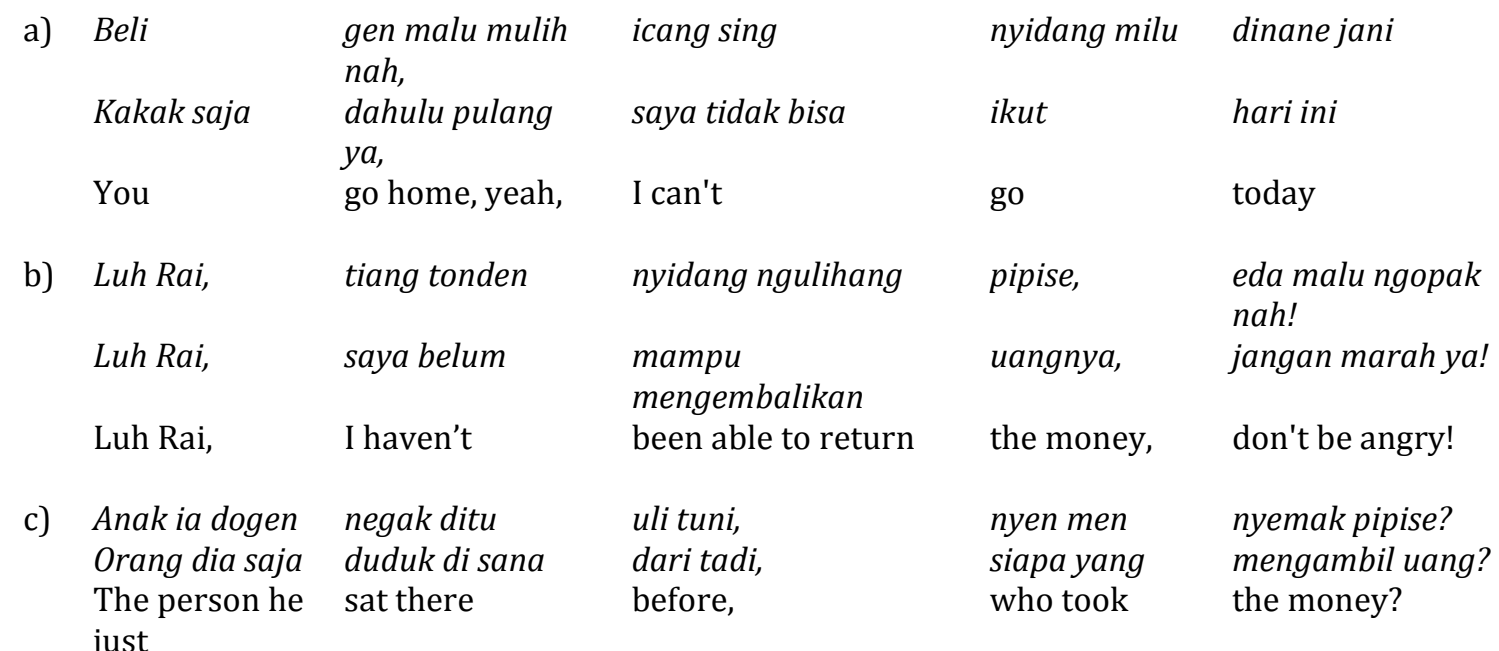

6) If the pronouns used in the language belong to rough level pronouns, unlike ake, iba, bangsate, naskeleng, it must be a sentence formed by a rough sentence. For example:

\begin{tabular}{|c|c|c|c|c|c|}
\hline \multirow[t]{2}{*}{ a) } & $\begin{array}{l}\text { Ih Cicing, } \\
\text { Ih anjing, }\end{array}$ & $\begin{array}{l}\text { ngudiang } \\
\text { mengapa }\end{array}$ & $\begin{array}{l}\text { ake dogen } \\
\text { aku saja }\end{array}$ & $\begin{array}{l}\text { orin iba } \\
\text { kamu surah }\end{array}$ & $\begin{array}{l}\text { mayah utange ditu? } \\
\text { membayar hutang di } \\
\text { situ? }\end{array}$ \\
\hline & Yes, dog, & why & only me & I ask & pay the debt there? \\
\hline \multirow[t]{3}{*}{ b) } & Dasar Iba & $\begin{array}{l}\text { jlema pongah } \\
\text { ngentut, }\end{array}$ & sabilang mai & sing ja ngaba & apa-apa \\
\hline & Dasar kamu & orang tak tau malu, & setiap ke mari & $\begin{array}{l}\text { tidak } \\
\text { membawa }\end{array}$ & ара-ара \\
\hline & $\begin{array}{l}\text { You } \\
\text { basically, }\end{array}$ & Don't know shame, & $\begin{array}{l}\text { every time } \\
\text { come }\end{array}$ & $\begin{array}{l}\text { You don't } \\
\text { bring }\end{array}$ & nothing \\
\hline c) & $\begin{array}{l}\text { Nyen } \\
\text { Siapa }\end{array}$ & $\begin{array}{l}\text { men kal pelihang } \\
\text { men patut }\end{array}$ & $\begin{array}{l}\text { sajawaning } \\
\text { kecuali }\end{array}$ & $\begin{array}{l}\text { Luh Rai } \\
\text { Luh Rai }\end{array}$ & $\begin{array}{l}\text { nas kelenge totonan? } \\
\text { bangsat itu? }\end{array}$ \\
\hline
\end{tabular}

Suwija, I. N. (2018). Role of anggah-ungguh kruna in Balinese language sentence formation. International Journal of Social Sciences and Humanities, 2(3), 21-32. https://doi.org/10.29332/ijssh.v2n3.187 


$\begin{array}{ll}\text { Wisalahkan } & \\ \text { Whould be blamed except } \quad \text { Luh Rai that's bastard? }\end{array}$

(1) alus singgih sentence, (2) alus sor sentence, (3) alus mider sentence, (4) alus madia sentence, (5) andap sentence, dan (6) kasar sentence.

\section{Conclusion}

The Balinese speech system is known to be complicated and unique because the Balinese language has a rude-smooth form called sor-singgih or anggah-ungguh basa. Balinese language sentence as a broader speech also has anggah-ungguh form. Based on the formation of anggah-ungguh kruna, Balinese language sentence is divided: (1) alus singgih sentence; (2) alus madia sentence; (3) alus sor sentence; (4) alus mider sentence, (5) andap sentence; and (6) kasar sentences. In the sentences formation, it is impossible for a sentence level to be formed by words that feel the same of the sensed value. The appearance of the word level as a sentence element will complement each other. That is, alus singgih sentence is impossible for all the words forming alus singgih words, etc. If it is closely looked, the level of the Balinese sentence can be seen from the pronoun (person) as the subject in the sentence. If the subject of the sentence included the sang singgih (upper class/caste), automatically the sentence is alus singgih, and so on.

\section{Acknowledgments}

The author would like to thank the reviewer of the journal for their consideration to enclose the study in the scope of the journal. The author as well as thanks to the editor of the journal for their support, valuable time, and advice. 


\section{References}

Djajasudarma, F. Fatimah. 2006. Metode Linguistik Ancangan Metode Penelitian dan Kajian.

Djiwandono, M. S. (1996). Tes bahasa dalam pengajaran. ITB Bandung.

Firdaus, W. (2011). Kata-Kata Serapan Bahasa Aceh Dari Bahasa Arab: Analisis Morfofonemis. Sosiohumaniora, 13(2), 223.

Ginaya, G. (2018). The Balinese calendar system: From its epistemological perspective to axiological practices. International Journal of Linguistics, Literature and Culture (IJLLC), 4(3), 24-37.

Koentjaraningrat, R. M. (1990). Pokok-pokok Antropologi Sosial. PT Dian Rakyat. Jakarta.

Naryana, I. B. U. (1983). Anggah-ungguhing basa Bali dan peranannya sebagai alat komunikasi bagi masyarakat suku Bali. Denpasar: Faculty of Letters, Unud.

Ramlan, M. (1981). Sintaksis. Yogyakarta, UP Karyono 1987. Morfologi Suatu Tinjauan Deskriptif.

Sofyan, A. N. (2015). Frasa Direktif yang Berunsur Di, Dari, Dan Untuk Dalam Bahasa Indonesia: Kajian Sintaktis dan Semantis. Sosiohumaniora, 17(3), 255-263.

Suarjana, P. I. N. (2011). Sor Singgih Bahasa Bali (ke-bali-an Manusia Bali Dalam Dharma Peparikan, Pidarta, Sambrama Wecana dan Dharma Wecana).

Sudaryanto, T. (1982). Metode Linguistik: Kedudukan, Aneka Isinya, dan Faktor Penentu Wujudnya. Yogyakarta: Fak. Sastra dan Kebudayaan, Universitas Gajah Mada.

Sudaryanto, T. (1993). Agribisnis komoditas hortikultura.

Suryasa, I. W., \& Dewi, A. A. S. C. (2018). Language maintenance of Balinese vocabulary in agriculture. International Journal of Linguistics, Literature and Culture, 4(4), 38-43.

Suwija, I. N. (2014). Tata titi mabaos Bali. Pelawa Sari.

Suwija, I. N. (2017). Identification of Anggah-ungguh Kruna Balinese language. International Journal of Linguistics, Literature and Culture (IJLLC), 3(6), 14-21.

Tarigan, H. G., \& Tarigan, D. (1986). Telaah buku tekst bahasa Indonesia. Angkasa.

Tinggen, I. N. (1984). Tata Bahasa Bali Ringkes.

Tinggen, I. N. (1995). Sor singgih basa Bali: istilah Indonesia-Bali. Rhika Dewata. 


\section{Biography of Author}

\begin{tabular}{|l|l||}
\hline Dr. Drs. I Nyoman Suwija, M.Hum., A.Ma. was born December 31st, 1963. He is \\
Hindu as a civil servant of Kopertis of Region VIII. He is a Senior Lecturer in IKIP \\
PGRI Bali, in 1987, he had finished his Bachelor Academic of Language and \\
Balinese Literature at the University of Udayana. He also had completed his \\
master in 2003 and doctor of the 2008 degree of the cultural studies at the same \\
university. \\
Email: inyoman.suwija63@gmail.com
\end{tabular}

